Eur J Clin Microbiol Infect Dis 1990;9:649-653.

21. Blumberg HM, Rimland D, Kiehlbauch JA, Terry PM, Wachsmuth IK. Epidemiologic typing of Staphylococcus aureus by DNA restriction fragment-length polymorphisms of rRNA genes: elucidation of the clonal nature of a group of bacteriophage-nontypeable, ciprofloxacin-resistant, methicillin-susceptible $S$ aureus isolates. J Clin Microbiol 1992;30:362-369.

22. Prevost G, Jaulhac B, Piemont Y. DNA fingerprinting by pulsedfield gel electrophoresis is more effective than ribotyping in distinguishing among methicillin-resistant Staphylococcus aureus isolates. J Clin Microbiol 1992;30:967-973.

23. Swaminathan B, Matar GM. Molecular typing methods. In: Persing DH, Smith TF, Tenover FC, White TJ, eds. Diagnostic Molecular Microbiology: Principles and Applications. Washington DC: American Society for Microbiology; 1994:26-50.

24. Venezia RA, Harris V, Miller C, Peck H, San Antonio M. Investigation of an outbreak of methicillin-resistant Staphylococcus aureus in patients with skin disease using DNA restriction patterns. Infect Cont Hosp Epidemiol 1992;13:472-476.

25. Fang FC, McClelland M, Guiney DG, et al. Value of molecular epidemiologic analysis in a nosocomial methicillin-resistant Staphylococcus aureus outbreak. JAMA 1993;270:1323-1328.

26. van Belkum A, Bax R, Peerbooms P, et al. Comparison of phage typing and DNA fingerprinting by polymerase chain reaction for discrimination of methicillin-resistant Staphylococcus aureus strains. J Clin Microbiol 1993;31:798-803.

27. Trilla A, Marco F, Moreno A, et al. Clinical epidemiology of an outbreak of nosocomial infection caused by Staphylococcus aureus resistant to methicillin and aminoglycosides: efficacy of control measures. Med Clin (Barc) 1993;100:205-209.

28. Craven DE, Reed C, Kollisch N, et al. A large outbreak of infections caused by a strain of Staphylococcus aureus resistant to oxacillin and aminoglycosides. Am J Med 1981;71:53-58.

29. Noel GJ, Kreiswirth BN, Edelson PJ, et al. Multiple methicillinresistant Staphylococcus aureus strains as a cause for a single outbreak of severe disease in hospitalized neonates. Pediatr Infect Dis 1992;11:184-188.

30. Nicole LE, Bialkowska-Hobrzanska H, Romance L, Harry VS, Parker S. Clonal diversity of methicillin-resistant Staphylococcus aureus in an acute-care institution. Infect Control Hosp Epidemiol 1992;13:33-37.

31. Trilla A, Nettleman MD, Hollis RJ, Fredrickson M, Wenzel RP, Pfaller MA. Restriction endonuclease analysis of plasmid DNA from methicillin-resistant Staphylococcus aureus: clinical application over a three-year period. Infect Control Hosp Epidemiol 1993;14:29-35.

\title{
MRSA Outbreak Within a Family
}

\section{by Gina Pugliese, RN, MS Medical News Editor}

Dr. A. J. Simpson and colleagues at St. Bartholomew's Hospital in London, England, recently reported an outbreak within a family of serious infection with methicillin-resistant Staphylococcus aureus (MRSA), including two cases of endocarditis related to injectable drug use.

The first case was an 8-year-old child who had a grommet insertion and an ear swab that grew MRSA that also was resistant to erythromycin. Eight months later, the 33-year-old mother of the child presented with a pain in her leg. She had been hospitalized 2 years earlier with cellulitis. Blood cultures grew MRSA, and an echocardiogram showed vegetation on the aortic and mitral valves. She subsequently developed septic arthritis of the hip and navicular osteomyelitis due to MRSA. Four months later, the 36-year-old husband of case 2 presented with rigors, and blood cultures grew MRSA with the same antibiogram and phage-typing patterns as the isolates from the wife and son. He was suspected to have endocarditis, and a repeat echocar- diogram after 4 weeks showed vegetation on the mitral valve.

This is believed to be the first reported outbreak of MRSA within a family. The original source of the MRSA is unclear. It is possible that either the mother or the son may have acquired the organism in the hospital, but dissemination within families is thought to be a rare event.

From: Simpson AJH, Anderson JR, Farfan GA. Family infection with methicillin-resistant Staphylococcus aureus. Lancet. 1995;36:914. 